\title{
The Possibility of APE1/Ref-1 as a Biomarker in the Detection of Coronary Artery Disease
}

\author{
Vipul Bhasin ${ }^{1}$, Busi Karunanand ${ }^{2}$, Sanjiv Kumar Bansal ${ }^{3}$, Vishu Bhasin ${ }^{4}$ \\ ${ }^{1}$ Resident doctor, Department of Biochemistry, SGT Medical college, Haryana, India, ${ }^{2} \mathrm{Head}$ of Department, Department of Biochemistry, SGT Medical college, \\ Haryana, India, ${ }^{3}$ Professor, Department of Biochemistry, SGT Medical college, Haryana, India, ${ }^{4}$ Consultant Pathologist, Dr P Bhasin Path Labs, New Delhi, India.
}

\section{Abstract}

Background: Coronary Artery Disease, was the leading cause of mortality globally resulting in more than 7 million deaths annually. APE1/Ref-1 is a multifunctional protein that is found in the nucleus of eukaryotic cells. Objective: To investigate the possibility of APE1/Ref-1 as a biomarker in the detection of Coronary Artery Disease in Indian population. Subjects and Methods: 100 subjects were divided into two groups of cases and controls. The Case group had Fifty patients diagnosed of Coronary Artery Disease on the basis of Clinical findings with Electrocardiography, Biochemical Markers, Echocardiography and Angiogram(wherever possible) attending the OPD of Department of Internal Medicine of SGT Hospital. Fifty age and gender matched healthy individuals constituted the control group. The data was statistically analyzed by using Student's t-test and P values $<0.05$ were considered statistically significant. Results: The difference in the mean of case and control values of APE1/Ref-1 is statistically significant. Conclusion: Our findings suggest that APE1/Ref-1 has a positive shows positive correlation with in patients of CAD.

Keywords: Coronary Artery Disease, APE1/Ref-1, Atherosclerotic Heart Disease, Atherosclerotic Cardiovascular Disease, Coronary Heart Disease.

Corresponding Author: Dr. Vipul Bhasin, Resident doctor, SGT Medical college, Haryana, India, E-mail ID: vipul@bhasinpathlabs.com

Received: January 2019

Accepted: February 2019

\section{Introduction}

As of 2010, Coronary Artery Disease, was the leading cause of mortality globally resulting in more than 7 million deaths annually. This has increased substantially from 5.2 million deaths in the year 1990. ${ }^{[1]}$ Some studies estimate that $60 \%$ of the global cardiovascular disease incidence will occur in the South Asian subcontinent even though it only accounting for $20 \%$ of the world's population. ${ }^{[2]}$ It is the biggest cause of death for both the sexes and amounts for around 6,00,000 deaths in the USA every year. ${ }^{[3]}$ Estimates from epidemiologic studies in various parts of India indicate a prevalence of Coronary Artery Disease(CAD) to be approximately $11 \%$ in urban population. ${ }^{[4]}$ All this is even after various preventive measures and treatments, like pharmacological, interventional, and surgical are extensively used to decrease the motility incidences. Early identification and prognostic assessment of CAD are important aspects. Biomarker can be instrumental in order to better identify high risk patients in population screenings, to better diagnose the disease, to successfully define the prognosis and therefore treat patients with the disease. ${ }^{[5,6]}$ APE1/Ref-1 is a multi-functional protein which is majorly found in the eukaryotic nucleus. It is an integral part of the base excision repair whereas Ref-1 acts as the reductive activator for multiple transcription factors in various cellular processes like cellular inflammation, angiogenesis, cell proliferation, apoptosis, and is required in cell survival pathways. ${ }^{[7,8]}$ There are numerous reports that modifications in the activity of APE1/Ref-1 are linked with numerous diseases, such as hypertension, cancer and neurodegenerative disease. ${ }^{[8-10]}$

DNA damage plays a very important part in the pathophysiology of CAD, modifications of APE1/Ref-1 might possibly happen in CAD. ${ }^{[1-13]}$ However, there were no studies narrating about the relationship of serum APE1/Ref-1 concentration in CAD for Indian population.

\section{Subjects and Methods}

The study was done in the Department of Biochemistry and the Department of Medicine at SGT Medical College, Hospital and Research Institute Budhera, Gurugram (Haryana). The study included 100 subjects divided into two groups of cases and controls. The Case group included Fifty patients diagnosed of Coronary Artery Disease based on Clinical findings with Electrocardiography, Biochemical Markers, Echocardiography and Angiogram(wherever possible) attending the OPD of Department of Internal Medicine of SGT Hospital. Fifty age and sex matched healthy individuals made the control group. The diagnosis of Coronary Artery Disease was be based on History, Clinical findings, Laboratory Investigations and 
Angiography, if available. Any individual with any acute or chronic inflammatory disease, any systemic disorder and any disorder of Liver, Kidney or Spleen were excluded from the study.

$5 \mathrm{ml}$ blood samples were withdrawn from the cubital vein after an overnight (12 hours) fasting. All the patients were informed about the aims of this study and a written consent were obtained from them before taking the blood sample. The serum was separated from blood by routine centrifugation for 15 minutes at 3,000 rpm and stored at $20^{\circ} \mathrm{C}$ until assayed. The estimation of APE1/Ref1 level was performed using sandwich enzyme-linked immunosorbent assay kit (LifeSpan BioSciences Inc.)

The serum levels of APE1/Ref1 were then compared in the case and control groups. The data was represented as mean \pm standard deviation (SD) and analyzed using SPSS software version 21. Comparison was done using Unpaired t-test/Mann-Whitney test, qualitative variables were expressed as frequencies/percentages and compared using Chi-square/Fisher's Exact test. $\mathrm{P}$ values $\leq 0.05$ were considered statistically significant.

\section{Results}

The case group consisted of 50 patients ( 27 males and 23 females) and the control group also had 50 patients (28 males and 22 females). Serum levels of APE1/Ref1 in all the patients with and without CAD was estimated. The serum levels of APE1/Ref1 in case group showed statistically significant differences from the control group.

\begin{tabular}{|c|c|c|c|c|c|}
\hline & Case & & Contr & & p-value \\
\hline & Mean & \pm SD & Mean & \pm SD & \\
\hline APE1/Ref1 & 3.77 & \pm 1.03 & 1.20 & \pm 0.7 & $<0.001$ \\
\hline
\end{tabular}

\section{Discussion}

Coronary Artery Disease, being the biggest cause of death globally. Its early identification and prognostic assessment of CAD are important aspects. Biomarker can be instrumental in order to better identify high risk patients in population screenings, to better diagnose the disease, to successfully define the prognosis and therefore treat patients with the disease. ${ }^{[5,6]}$

APE1/Ref-1 is a multi-functional protein which is majorly found in the eukaryotic nucleus. Its modification in expression has been deeply researched in neurodegenerative diseases and oncology but only a very few researches are available with its linkage to Coronary Artery Disease.

Our study showed that the difference in the mean of case and control values of APE1/Ref-1is statistically significant. This shows positive correlation in patients of CAD.

Few other studies in the past had found similar results. Seon-Ah Jin et al, ${ }^{[14]}$ (2015) investigated serum APE1/Ref-1 in 360 patients with CAD. They concluded that the levels of APE1/Ref-1 in serum were increased in patients of CAD, and were significantly higher in myocardial infarction when compared with angina. APE1/Ref-1 also showed a positive correlation with Troponin I values.

There are a lot of conditions which have increased levels of APE-1/Ref-1 in serum, like in inflammations, hypertension, oncology, atherosclerosis, and a lot of other conditions. ${ }^{[14]}$

Martinet et al. ${ }^{[15]}$ stated that APE1/Ref-1 works as an enzyme for DNA repair and is increased in atherosclerotic plaques in humans. APE1/Ref-1 levels are seen to be elevated and activated for ischemia and reperfusion, hypoxia and radiation. Although a lot of reports have discussed that APE1/Ref-1 is located only in the nucleus and the process for APE1/Ref-1 in serum is completely explained, but it was very recently found that APE1/Ref-1 was released in the blood in reciprocation to lipopolysaccharides. ${ }^{[16,17]}$ Knowing that CAD is clearly linked with inflammation, and ischemia and reperfusion injuries, the increase of APE1/Ref-1 levels of serum in patients was naturally expected.

It is a well accepted fact that activation of APE1/Ref- 1 is an important step for protection from oxidative stresses. ${ }^{[18]}$ Also it has been well proven that the over expression of APE1/Ref-1 helps in the prevention of cell deaths due to $\mathrm{H} 2 \mathrm{O} 2 .^{[19,20]}$ So, we believe that the increase of APE1/Ref-1 is directed linked to oxidative injury of the myocardial tissue and vessel wall, and the reason for the elevation is to prevent cell death. We suggest that increase in the serum levels of APE1/Ref-1 might be related to damage in vessel wall not myocardial tissue damage.

The study had some limitations related to small sample size; we included samples from both the groups we examined, but not all of the samples for APE1/Ref-1 were withdrawn at a specific time. Even though we excluded all possible diseases which could interfere with our results such as cases of chronic inflammation and all oncology patients, we could not completely banish the possibility of other pathologies that could have seeded the alteration in the values of APE1/Ref-1. The possibility of alteration in results due medication could not be ruled out completely for and should be considered.

\section{Conclusion}

In conclusion, we established that the serum levels of APE1/Ref-1 may be elevated in patients with CAD. But larger and more detailed studies are needed to evaluate its use as a biomarker in the diagnostic and prognostic use in CAD which should include more details about the patient's history and conditions such as history of angina or myocardial infarction, patient's ejection franction and peak Troponin levels at the time of injury.

In conclusion, our findings statistically suggest that the serum levels of APE1/Ref-1 levels are elevated in patients of CAD, but larger studies would be required to find the exact usefulness of APE1/Ref-1.

\section{References}

1. Lozano R, Naghavi M, Foreman K, Lim S, Shibuya K, Aboyans V, Abraham J, Adair T, Aggarwal R, Ahn SY, et al. Global and regional mortality from 235 causes of death for 20 age groups in 1990 and 
2010: a systematic analysis for the Global Burden of Disease Study 2010. Dec 2012; Lancet 380 (9859): 2095-128.

2. Indian Heart Association Why South Asians Facts Web. 29 April 2015. <http://indianheartassociation.org/why-indians-why-southasians/overview/

3. Kenneth D , Kochanek M.A., Jiaquan Xu, M.D.,Sherry L. Murphy, B.S.; Arialdi M. Miniño, M.P.H., Hsiang-Ching Kung, Ph.D.; Retrieved 25 March 2013.

4. Mohan V., Deepa R., Rani S.S. Prevalence of coronary artery disease and its relationship to lipids in a selected population in South India. J Am Coll Cardiol ; 2001;38:682-87.

5. Kim HC. Clinical utility of novel biomarkers in the prediction of coronary heart disease. Korean Circ J 2012;42:223-8.

6. 2. Vasan RS. Biomarkers of cardiovascular disease: molecular basis and practical considerations. Circulation 2006;113:2335-62

7. Tell G, Quadrifoglio F, Tiribelli C, Kelley MR. The many functions of APE1/Ref-1: not only a DNA repair enzyme. Antioxid Redox Signal; 2009;11:601-20

8. Thakur S, Sarkar B, Cholia RP, Gautam N, Dhiman M, Mantha AK. APE1/Ref-1 as an emerging therapeutic target for various human diseases: phytochemical modulation of its functions. Exp Mol Med 2014;46:e106

9. Naganuma T, Nakayama T, Sato N, et al ; Haplotype-based case-con trol study on human apurinic/apyrimidinic endonuclease 1/redox effector factor-1 gene and essential hypertension. Am J Hypertens 2010;23:186-91.

10. Zhang Y, Wang J Xiang D, Wang D, Xin X. Alterations in the expression of the apurinic/apyrimidinic endonuclease-1/redox effector factor-1 (APE1/Ref-1) in human ovarian cancer and indentification of the therapeutic potential of APE1/Ref-1 inhibitor. Int $\mathrm{J}$ Oncol 2009;35:1069-79.

11. Botto N, Rizza A, Colombo MG, et al ; Evidence for DNA damage in patients with coronary artery disease. Mutat Res 2001;493:23-30.

12. Mahmoudi M, Mercer J, Bennett M. DNA damage and repair in atherosclerosis. Cardiovasc Res 2006;71:259-68

13. Martinet W, Knaapen MW, De Meyer GR, Herman AG, Kockx MM Elevated levels of oxidative DNA damage and DNA repair enzymes in human atherosclerotic plaques. Circulation 2002;106:927-32.

14. Seon-Ah Jin et al. Elevation of the Serum Apurinic/Apyrimidinic Endonuclease 1/Redox Factor-1 in Coronary Artery Disease. Korean Circulation Journal. 2015; 45(5):364.

15. Martinet W, Knaapen MW, De Meyer GR, Herman AG, Kockx MM. Elevated levels of oxidative DNA damage and DNA repair enzymes in human atherosclerotic plaques. Circulation. 2002;106:927-932.

16. Park MS, Lee YR, Choi S, et al. Identification of plasma APE1/Ref-1 in lipopolysaccharide-induced endotoxemic rats: implication of serological biomarker for an endotoxemia. BiochemBiophys Res Commun. 2013;435:621-626.

17. Choi S, Lee YR, Park MS, et al. Histone deacetylases inhibitor trichostatin A modulates the extracellular release of APE1/Ref-1. BiochemBiophys Res Commun. 2013;435:403-407.

18. Pines A, Perrone L, Bivi N, et al. Activation of APE1/Ref-1 is dependent on reactive oxygen species generated after purinergic receptor stimulation by ATP. Nucleic Acids Res. 2005;33:4379-4394.

19. Vasko MR, Guo C, Kelley MR. The multifunctional DNA repair/redox enzyme Ape1/Ref-1 promotes survival of neurons after oxidative stress. DNA Repair (Amst) 2005;4:367-379.

20. Wang D, Luo M, Kelley MR. Human apurinic endonuclease 1 (APE1) expression and prognostic significance in osteosarcoma: enhanced sensitivity of osteosarcoma to DNA damaging agents using silencing RNA APE1 expression inhibition. Mol Cancer Ther. 2004;3:679-686.

Copyright: (C) the author(s), 2019. It is an open-access article distributed under the terms of the Creative Commons Attribution License (CC BY 4.0), which permits authors to retain ownership of the copyright for their content, and allow anyone to download, reuse, reprint, modify, distribute and/or copy the content as long as the original authors and source are cited.

How to cite this article: Bhasin V, Karunanand B, Bansal SK, Bhasin V. The Possibility of APE1/Ref-1 as a Biomarker in the Detection of Coronary Artery Disease. Asian J. Med. Res. 2019;8(1):BC01-BC03.

DOI: dx.doi.org/10.21276/ajmr.2019.8.1.BC1

Source of Support: Nil, Conflict of Interest: None declared. 